\title{
Personality attributes making significant influence on the digital quotient of an individual: An exploratory Study
}

\author{
Rahul Shandilya \\ President and Group CIO, Welspun Group, India \\ Scholar for Doctoral Studies, NIIT University, India, Email: rahul.shandilya@st.niituniversity.in \\ $\&$ \\ Prof Neeti Mathur, \\ Asst. Professor, Management, NIIT University. Email: neeti.mathur@niituniversity.in \\ \& \\ Prof Sushil Kalyani, \\ Area Director, Management, NIIT University. Email: sushik@niituniversity.in
}

\begin{abstract}
The digital divide in the society has been a key demographic factor which has impacted the social economic activities in recent times. The digitalization of erstwhile social \& economic models harbingers a distinct change in behaviors of various sections of the society. Policy makers in various organizations and civic administrators are studying this new age individual's response to manage their reach out strategies via digital medium. Correspondingly acquiring or nurturing talent with higher digital quotient would help organizations better adapt to new age business models.
\end{abstract}

No two human beings are identical and therefore it is important to understand what makes an individual display a higher digital quotient. The aim of the current research study is to understand key personality attributes which have high influence on an individual's response to a stimulus sent thru a digital medium.

The online primary survey was conducted on a random sample of 83 people over a period between March 19 and Jun 20. It sought to identify most relevant attributes to define a digital persona. The study ended in concluding overall six personality attributes which have key influence while each one of them had a distinct measure of impact.

Key Words: digital quotient, personality attributes, online, digital awareness, online behavior.

Digital Intelligence $(D Q)^{14}$ is a comprehensive set of technical, cognitive, meta-cognitive, and socio-emotional competencies that are grounded in universal moral values and that enable individuals to face the challenges and harness the opportunities of digital life.

INTRODUCTION: Digital medium is fast becoming a key sales and distribution channel across Industries globally. Research by Karan Choudhary 2016 suggested that ECommerce business GMV is projected to be $\$ 60$ Billion by 2020. An early research by Peterson, Sridhar Balasubramanian \& Bart J Bronnenberg (1997) suggested that ecommerce purchases are normally categorized in two segments - search based and experience based. The end user engagement and their preferences on digital platforms is a crucial factor in any of the online transactions. The personality attributes influencing the engagement behavior of an individual on a digital medium are keenly observed by any organization investing in growth in the channel. As 
individuals continue to evolve their virtual profiles, this study undertakes to assess key personality attributes which makes an individual actively respond to any stimulus sent over a digital medium. The proposed research provides an enlisting of all attributes which may have an impact on identifying individuals with higher digital quotient.

\section{STATEMENT OF THE PROBLEM}

Digital medium is a fast growing environment where consumers are engaging to make transactions related to information, communication, goods and services. A wider research, as mentioned in the literature review has been done over last 2 decades on emerging digital technologies \& their application design \& features which make these digital medium effective in engaging target individuals. The research has been focused towards the technology platform's features, design, offerings and user interface (UI/UX) so as to create \& improve engagement with the visitors.

However not enough has been researched on correlation between an array of key personality / behavioral attributes and their influence on an individual's response towards stimulus generated on any digital medium.

Thus "Improvement / personalization of digital platform by associating it with personality attributes" is an area which gives opportunity for a further research. If we make progress in this space then the findings may help in better assessment of society / consumer / employees and accordingly action can be taken by policy makers / marketers / HR managers.

\section{OBJECTIVE OF THE STUDY}

To identify key personality traits which have influence on an individual's response towards stimulus sent on a digital environment

\section{REVIEW OF THE PREVIOUS STUDIES}

Alexandros Alexiou, Dean Riddlesden and Alex Singleton (2018), analyzed the consumer's buying behaviors between offline and online medium and concluded that the influencing factors are financial savings, information availability and convenience of buying.

Blanca Hernandez et al. (2011) analyzed impact of socio-economic factors on the buying patterns of the users and concluded that they have major impact in the early days of the user buying. Once the users become accustomed to the digital buying the impact is minimal and no more creates a differentiated impact.

DannyAzucar, DavideMarengo \& MicheleSettanni (2017) worked on meta-analysis on social media data and studied predictive power of the digital footprints across social media to derive the top 5 personality traits of an individual. Overall, their findings indicate that accuracy of predictions is consistent across Big 5 traits, and that accuracy improves when analyses include demographics and multiple types of digital footprints. 
Dr. N.Balakrishnan (2018) studied the factors influencing the behavior of the rural consumer and concluded that economic, social and psychological factors are all important towards making a consumer engage effectively on the digital platforms.

Kuan-Pin \& Ruby Roy Dholakia (2003) identified that convenience is a biggest drive for online buying by the consumer. Also consumers generally engage more on digital platform is they are looking for search based goods / services rather than experience based goods.

Marios Koufaris, Ajit Kambil, and Priscilla Ann LaBarbera (2002) studied the consumer behavior in the web based commerce and observed that perceived control and enjoyment of a visitor towards planned purchases can improve the chances of return of the consumer to a website. The consumers used value added search as a factor which may influence the un planned purchases.

Pentina Iryna and Taylor, David G (2010) in an exploratory study worked on the similarity between a virtual avatar of based end user engagement and observed that low involvement purchase conditions the online factors make a difference whereas for high involvement purchase conditions the traditional sales criteria makes the difference.

STEVEN BELLMAN, GERALD L. LOHSE and ERIC J. JOHNSON (1999) worked on the predictors of the online buying behaviors and proposed that information gatherer behavior when coupled with convenience shall incline a consumer to come to a digital platform.

S. Saranya and Dr. S.Poongodi (2015) studied the consumer's buying behavior towards the online shopping and concluded that discounting and user convenience drives the users towards transacting online.

Tsai Chen and Ming-Chang Lee (2015), studied the personality traits which impact the impulsive buying on online platforms and concluded that three elemental traits - agreeableness, need for arousal, and need for material - are predictive of online buying impulsiveness. Middle level trait of value consciousness is mediating the effect of conscientiousness and negatively associated with the dependent variable

Viswanath Venkatesh and Ritu Agarwal (2006) concluded that stickiness of a digital platform provides for better consumer engagement and improves the changes of making a purchasing transaction. The stickiness may come because of the effective usage of technologies towards engagement or usability of the site from user behavior perspective.

\section{RESEARCH GAPS}

The research done over decades has brought up findings into design \& features of the technology platforms including UI/UX for better engagement towards search / experienced goods \& services. Some studies also highlighted how the consumer buying behavior is influenced by these platforms compared to traditional non digital methods. 
However the fast evolving digitalization of socio-economic models are also redefining individual's personas (let us call digital profiling) which may influence a consumer behaviors especially on digital mediums.

The above said researches don not have much to share on the aspects of personality attributes and their influence on the behaviors towards digital platforms. This new emerging areas brings in a gap which has been researched in this paper.

The focus of this research paper was to study which personality attributes have higher influence on an individual's comfort towards using digital medium.

\section{RESEARCH METHODOLOGY}

The methodology adopted was descriptive and the study was conducted in two phases leveraging online / telephonic survey with respondents in three different cities in India.

The phase one was exploratory \& qualitative in nature and consisted of a questionnaire of 10 open ended questions asking for respondents view on various aspects of user's behaviors in the digital environment. A total of 83 respondents gave subjective answers which consisted of 853 key behavioral descriptions allowing repetition of the words. Using word cloud analysis these key behavior descriptions were reduced to 10 key behaviors and finally to 6 personality attributes. These were put as a framework called as UCCCEE (Updated, Confident, Connected, Curious, Experimentative and Efficient) not necessarily in same order.

A conclusive survey was done with a follow up telephonic survey where 20 people responded out of 83 above seeking their scaled responses from 0 to 100 on impact made by these 6 attributes towards them being digitally comfortable on transacting over any digital medium.

\section{Research Design}

To conduct this study "descriptive research methodology' was used where the data has been collected from defined sample for the research.

\section{Area \& Period of study}

The period of study was March 2019 to June 2020. The country was India and metro cities were considered as - Mumbai, Delhi and Pune.

\section{Sampling Technique}

The sample respondents were randomly selected from 03 metro cities in India considering that these are among the most active users on digital tools in India. (Data ${ }^{15}$ published on www.dot.gov.in 2018). The primary source of data was used to conduct this study. A total of 112 respondents were approached, out of which 83 responded.

\section{Sources of data}

Primary sources were individual respondents who were contacted through an online /telephonic survey. 


\section{Limitations of the study}

The study is exploratory in nature and brings in basic understanding of key behavioral attributes only. The geography is in metro cities in India given the digital penetration is more in urban settlements. The findings of these study are not validated in other part of the world. To ascertain a more generalize, reliable and significant conclusion, a further study employing psychometric tests on a larger sample size and all section of consumers will be needed.

\section{DATA ANALYSIS AND INTERPRETATION}

The data was collected using a simple structured subjective questionnaire asking to describe a digitally savvy person. A total of 10 open ended questions on the subject were asked to respondents who provided words/phrase which best represented their views on the question. Each question could have answers with more than one word / phrase. Overall 853 relevant word/phrases were collected from all the answers given.

A word cloud was created for every question to select those words which were most frequently used by respondents on each question. Thus highest frequency words were identified and thereafter top 5 ranked words were shortlisted against each question. As next step factor analysis method was used to identify the most influencing connotation of these words.

TABLE 1.0: DEMOGRAPHIC CONSIDERATION OF THE RESPONDENTS

\begin{tabular}{|l|l|l|}
\hline Category & Frequency & Percentage \\
\hline Gender & & \\
\hline Male & 60 & $72 \%$ \\
\hline Female & 23 & $28 \%$ \\
\hline Age Group & & \\
\hline Below 30 & 24 & $28 \%$ \\
\hline Between 30-40 & 30 & $36 \%$ \\
\hline Above 40 & 29 & $34 \%$ \\
\hline Education & & \\
\hline Technical & 42 & $51 \%$ \\
\hline Non-Technical & 41 & $49 \%$ \\
\hline Graduate & 49 & $59 \%$ \\
\hline Post Graduate & 34 & $41 \%$ \\
\hline Working Status & & \\
\hline Working & 66 & $79 \%$ \\
\hline Not Working & 17 & $21 \%$ \\
\hline Married Status & & \\
\hline Married & 69 & $83 \%$ \\
\hline Unmarried & 14 & $17 \%$ \\
\hline Financial Status & & \\
\hline
\end{tabular}




\begin{tabular}{|l|l|l|}
\hline Average earning pa & 35.8 Lacs INR & NA \\
\hline Median & 35.5 Lacs INR & NA \\
\hline STD Dev & 21.32 & NA \\
\hline
\end{tabular}

The youngest respondent was of 19 years of age and oldest was of 55 years of age. The average age was 37.1 years and median was 40 years and STD Dev was 8.9. All respondents have had a smart phone and had conducted an online purchase in last 1 year. They had a social media account and were active at least on one such handle.

\section{TABLE 2.0: QUESTION AND ATTRIBUTES FREQUENCY AS GATHERED}

The table below provides an analysis of the factors which captured higher frequency among the respondents as per question asked in the questionnaire.

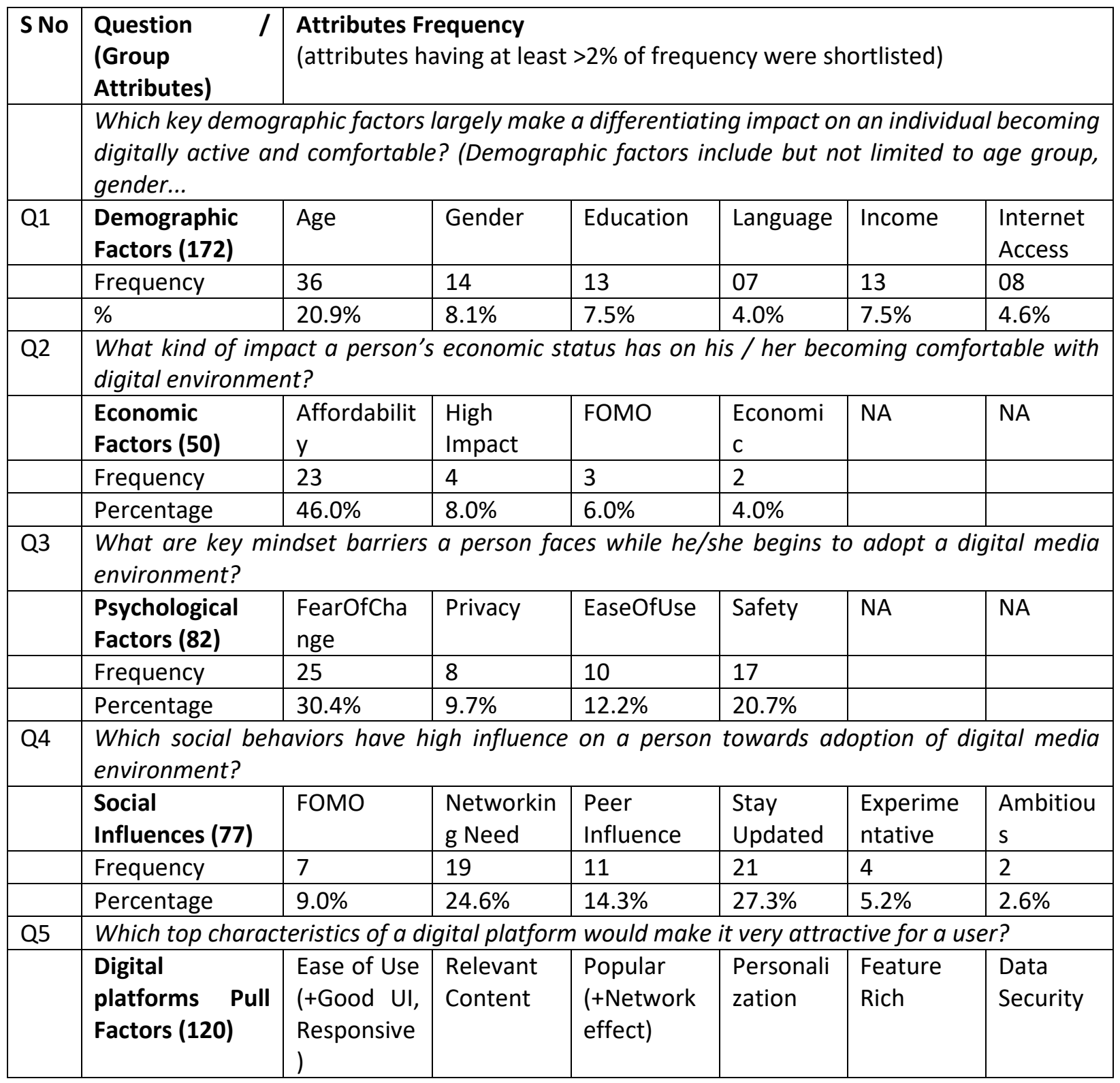




\begin{tabular}{|c|c|c|c|c|c|c|c|}
\hline & Frequency & 54 & 16 & 10 & 26 & 07 & 08 \\
\hline & Percentage & $45.0 \%$ & $13.3 \%$ & $8.3 \%$ & $21.6 \%$ & $5.8 \%$ & $6.6 \%$ \\
\hline Q6 & \multicolumn{7}{|c|}{$\begin{array}{l}\text { What kind of information inflow around a person makes him/her more influenced and therefore } \\
\text { more digital savvy? }\end{array}$} \\
\hline & $\begin{array}{l}\text { Information } \\
\text { Influx factors } \\
\text { (75) }\end{array}$ & $\begin{array}{l}\text { Social } \\
\text { Circle Info }\end{array}$ & News & Trending & Updates & $\begin{array}{l}\text { Convenien } \\
\text { ce }\end{array}$ & Chatting \\
\hline & Frequency & 15 & 7 & 12 & 24 & 2 & 7 \\
\hline & Percentage & $20.0 \%$ & $9.3 \%$ & $16.0 \%$ & $32.0 \%$ & $2.6 \%$ & $9.3 \%$ \\
\hline Q7 & \multicolumn{7}{|c|}{$\begin{array}{l}\text { What kind of skills or education of an individual makes him/her more open and adoptive of digital } \\
\text { media? }\end{array}$} \\
\hline & $\begin{array}{l}\text { Education } \\
\text { Factors (67) }\end{array}$ & $\begin{array}{l}\text { Curiosity to } \\
\text { learn }\end{array}$ & $\begin{array}{l}\text { Education } \\
\text { Independ } \\
\text { ent }\end{array}$ & Innovation & $\begin{array}{l}\text { Logical } \\
\text { Reasonin } \\
\mathrm{g}\end{array}$ & $\begin{array}{l}\text { Language } \\
\text { Skills }\end{array}$ & $\begin{array}{l}\text { Technolo } \\
\text { gy Skills }\end{array}$ \\
\hline & Frequency & 12 & 7 & 6 & 5 & 16 & 8 \\
\hline & Percentage & $17.9 \%$ & $10.4 \%$ & $8.9 \%$ & $7.4 \%$ & $23.8 \%$ & $11.9 \%$ \\
\hline $\mathrm{Q} 8$ & \multicolumn{7}{|c|}{ What would impress you most among your peers who are digitally savvy? } \\
\hline & $\begin{array}{l}\text { Peer Pressure } \\
\text { factors }(68)\end{array}$ & $\begin{array}{l}\text { Always } \\
\text { Updated }\end{array}$ & Efficient & Connected & $\begin{array}{l}\text { Self- } \\
\text { Confiden } \\
t\end{array}$ & Curiosity & Popular \\
\hline & Frequency & 17 & 12 & 4 & 5 & 6 & 4 \\
\hline & Percentage & $25.0 \%$ & $17.64 \%$ & $5.8 \%$ & $7.4 \%$ & $8.8 \%$ & $5.8 \%$ \\
\hline Q9 & \multicolumn{7}{|c|}{ How does an individual's behavior vary from physical world to digital world - or are they same? } \\
\hline & $\begin{array}{l}\text { Phygital Factors } \\
\text { (67) }\end{array}$ & $\begin{array}{l}\text { Different } \\
\text { Profiling }\end{array}$ & $\begin{array}{l}\text { Express } \\
\text { Freely }\end{array}$ & $\begin{array}{l}\text { Virtual } \\
\text { avatar }\end{array}$ & $\begin{array}{l}\text { Extreme } \\
\text { ended } \\
\text { expressio } \\
\text { ns }\end{array}$ & $\begin{array}{l}\text { Digital } \\
\text { Adventuro } \\
\text { us }\end{array}$ & $\begin{array}{l}\text { Touch \& } \\
\text { feel }\end{array}$ \\
\hline & Frequency & 17 & 10 & 19 & 11 & 3 & 4 \\
\hline & Percentage & $25.3 \%$ & $14.9 \%$ & $28.3 \%$ & $16.4 \%$ & $4.4 \%$ & $5.9 \%$ \\
\hline Q10 & \multicolumn{7}{|c|}{$\begin{array}{l}\text { Does workplace makes you more digitally active or your home influence? Which attributes play } \\
\text { key role at either place? }\end{array}$} \\
\hline & $\begin{array}{l}\text { Work Space } \\
\text { Factor (121) }\end{array}$ & $\begin{array}{l}\text { Office } \\
\text { More } \\
\text { Influencer }\end{array}$ & $\begin{array}{l}\text { Office } \\
\text { efficiency }\end{array}$ & $\begin{array}{l}\text { Office } \\
\text { Networkin } \\
\mathrm{g}\end{array}$ & $\begin{array}{l}\text { Office } \\
\text { Learning }\end{array}$ & $\begin{array}{l}\text { Home } \\
\text { Happiness }\end{array}$ & $\begin{array}{l}\text { Home } \\
\text { Entertain } \\
\text { ment }\end{array}$ \\
\hline & Frequency & 34 & 14 & 13 & 10 & 08 & 16 \\
\hline & Percentage & $28 \%$ & $11.5 \%$ & $10.7 \%$ & $8.2 \%$ & $6.6 \%$ & $13.2 \%$ \\
\hline
\end{tabular}

\section{TABLE 3.0: ANALYSIS OF THE FACTORS / ATTRIBUTES WITH HIGHER FREQUENCY}

The table below provides deduction of all factors into more finer and smaller group without losing the effectiveness.

\begin{tabular}{|l|l|l|l|l|l|}
\hline $\mathbf{Q}$ & $\begin{array}{l}\text { Factor (s) with } \\
\text { higher frequency }\end{array}$ & $\begin{array}{l}\text { Interpretation } \\
\mathbf{1}\end{array}$ & Behaviors & $\begin{array}{l}\text { Personality } \\
\text { Attributes }\end{array}$ & $\begin{array}{l}\text { Framework } \\
\text { (copy righted) }\end{array}$ \\
\hline Q1 & Age & Eager to know & Inquisitiveness & Curious & \\
\hline
\end{tabular}




\begin{tabular}{|c|c|c|c|c|c|}
\hline Q2 & Affordability & Exchange & Confident & Confident & \multirow{9}{*}{$\begin{array}{l}\text { UCCCEE } \\
\text { (Updated, } \\
\text { Curious, } \\
\text { Confident, } \\
\text { Connected, } \\
\text { Experimentativ } \\
\text { e, Efficient) }\end{array}$} \\
\hline Q3 & $\begin{array}{l}\text { Fear of Change }+ \\
\text { Safety }\end{array}$ & Resilient & Confident & Confident & \\
\hline Q4 & $\begin{array}{l}\text { Networking +Stay } \\
\text { Updated }\end{array}$ & $\begin{array}{l}\text { Connected + } \\
\text { Updated }\end{array}$ & Connected & $\begin{array}{l}\text { Connected } \quad+ \\
\text { Updated }\end{array}$ & \\
\hline Q5 & $\begin{array}{l}\text { Ease of use }+ \\
\text { Personalization }\end{array}$ & Efficient & Efficient & Efficient & \\
\hline Q6 & $\begin{array}{l}\text { Social circle info + } \\
\text { Updates }+ \text { Trending }\end{array}$ & $\begin{array}{l}\text { Connected + } \\
\text { Updated }\end{array}$ & $\begin{array}{l}\text { Connected } \quad+ \\
\text { Updated }\end{array}$ & $\begin{array}{l}\text { Connected } \\
\text { Updated }\end{array}$ & \\
\hline Q7 & $\begin{array}{l}\text { Curiosity of learning } \\
+\quad \text { Language } \\
\text { Technology Skills }\end{array}$ & Curious & Curious & Curious & \\
\hline Q8 & $\begin{array}{l}\text { Always updated + } \\
\text { Efficient }\end{array}$ & Updated & Aware & Updated & \\
\hline Q9 & $\begin{array}{l}\text { Different profiling }+ \\
\text { Virtual Avatar }\end{array}$ & Alter-profile & Experimenter & Experimentative & \\
\hline Q10 & $\begin{array}{l}\text { Office } \\
\text { Influencer }+ \text { More } \\
\text { efficiency }\end{array}$ & $\begin{array}{l}\text { Output driven } \\
+ \text { Efficient }\end{array}$ & Efficiency & Efficient & \\
\hline
\end{tabular}

The observations and interpretation in the study done above with closer look at factor analysis has helped the researcher to conclude the following personality attributes as key differentiators. The description states the responsive behavior against the stated attribute. (See the table 4.0)

The author of this paper has adopted the framework as UCCCEE to effectively communicate the findings and recall. He carries a copyright on this acronym.

\section{TABLE 4.0: UCCCEE FRAMEWORK ${ }^{\odot}$}

\begin{tabular}{|l|l|l|}
\hline SI. No & Attribute Type & Description \\
\hline 1 & UPDATED & Information gatherer \\
\hline 2 & CURIOUS & Inquisitiveness towards knowing more \\
\hline 3 & CONFIDENT & Ability and willingness to trade off with unknowns ahead \\
\hline 4 & CONNECTED & Social profile and relatability for existence \\
\hline 5 & EXPERIMENTATIVE & Open to newer ideas and willing to approach / adopt them \\
\hline 6 & EFFICIENT & Productivity matter on time \& efforts \\
\hline
\end{tabular}

\section{VALIDATION OF THE FRAMEWORK}

A further online survey with smaller group from earlier respondents was carried out to ascertain whether the individuals would agree to the findings. Total of 20 individual's responded against the UCCEEE framework on whether they agree with each of the attributes. The respondents were also asked to provide their rating score on impact these attributes makes on a scale of 100 . The table 5.0 provides for the analysis of this validation survey. 
TABLE 5.0: UCCCEE FRAMEWORK VALIDATION SURVEY FINDINGS

\begin{tabular}{|l|l|l|l|}
\hline $\begin{array}{l}\text { Survey Cronbach's Alpha } \\
\text { Score }\end{array}$ & 0.81 & \multicolumn{2}{l|}{} \\
\hline Target Participants & $\begin{array}{l}83 \text { (same as above who took first test) } \\
\text { Responded : 20 }\end{array}$ & Max Score* \\
\hline Attribute & $\begin{array}{l}\text { Average Affirmative } \\
\text { Impact Score }\end{array}$ & Min Score* & 97 \\
\hline UPDATED & 85.8 & 55 & 97 \\
\hline CURIOUS & 79.35 & 41 & 95 \\
\hline CONFIDENT & 60.6 & 04 & 90 \\
\hline CONNECTED & 69.25 & 25 & 95 \\
\hline EXPERIMENTATIVE & 76.2 & 50 & 95 \\
\hline EFFICIENT & 64.65 & 03 & \\
\hline
\end{tabular}

*: score of 100 and 0 are replaced by nearest score

\section{CONCLUSION}

This study mainly analyzed the personality attributes influencing an individual's response to adopting digital medium in their life. The research findings reveals that digital quotient of an individual is relational to certain personality attributes. Among many the key personality attributes were identified as a framework named UCCCEE. The acronym stands as U-updated, Ccurious, C-confident, C-connected, E-Experimentative and E-efficient.

The most influencing factor remains "Updated" and lowest being "Confident". The digital technologies are yet to establish their socio-economic advantages in the respondent's view therefore they rate lower on "Efficiency". The younger generation doesn't consider "Confident" as a necessary attribute as they don't have to shift from an old baseline to new. They begin their behavior set on digital baseline itself.

\section{SCOPE FOR FUTURE RESEARCH}

This study is confined to identifying personality attributes which have significant influence on an individual's response towards digital medium. A further study towards defining an individual's profile based on UCCCEE framework need to be made so as to assess more effective outcome wrt to social, economic behaviors. Further study wrt to correlational relationship between these profiles and online transactions may help to understand who is a better \& fruitful target towards reach outs by organizations.

\section{REFERENCES}

1. Alexandros Alexiou, Dean Riddlesden and Alex Singleton (2018), The Geography of Online Retail Behaviour, Stable URL: https://www.jstor.org/stable/j.ctvqhsn6.10 
2. Blanca Hernández, Julio Jiménez and José Martín M. (2011), "Age, gender and income: do they really moderate online shopping behavior?", Online Information Review, Vol. 35, Iss: 1 , pp: $113-133$.

3. DannyAzucar, DavideMarengo, MicheleSettanni, 2017, Predicting the Big 5 personality traits from digital footprints on social media: A meta-analysis. Elsivier, Volume 124, 1 April 2018, Pages 150-159

4. Dr. N.Balakrishnan (2018), Factors Influencing The Buying Behaviour Of Rural Consumer Through Online In Karur District, www.theinternationaljournal.org> RJCBS : Volume: 07, Number: 06, April 2018

5. Kuan-Pin Chiang School of Business, Brooklyn Campus Long Island University \& Ruby Roy Dholakia College of Business Administration University of Rhode Island, Factors Driving Consumer Intention to Shop Online: An Empirical Investigation, JOURNAL OF CONSUMER PSYCHOLOGY, 13(1\&2),177- 183 Copyright (C2003, Lawrence Erlbaum Associates, Inc.

6. Karan Choudhary June1st 2016, https://www.businessstandard.com/article/companies/e-commerce-to-reach-60-bn-gmv-by-2020116053101358_1.html

7. Marios Koufaris, Ajit Kambil, and Priscilla Ann LaBarbera, Consumer Behavior in WebBased Commerce: An Empirical Study, International Journal of Electronic Commerce / Winter 2001-2002, Vol. 6, No. 2, pp. 115-138. Copyright (C) 2002 M.E. Sharpe, Inc

8. Peterson, Sridhar Balasubramanian \& Bart J Bronnenberg. exploring the implications of the internet for consumer marketing, 1997, Journal of Academy of Marketing Science, Article No 329.

9. Pentina Iryna and Taylor, David G (2010) Exploring source effects for online sales outcomes: The role of avatar buyer similarity. Journal of Customer Behavior. Summer 2010 Vol 9 Issue 2, p135150

10. STEVEN BELLMAN, GERALD L. LOHSE and ERIC J. JOHNSON. Predictors of online buying behavior. December 1999/Vol 42. No 12 COMMUNICATIONS OF THE ACM

11. S. Saranya and Dr.S.Poongodi, Consumers' Buying Behavior Towards Online Shopping An Empirical Study In Bangalore City, www.theinternationaljournal.org > RJCBS: Volume: 05, Number: 02, December-2015

12. Tsai Chen and Ming-Chang Lee (2015), Personality Antecedents of Online Buying Impulsiveness, Journal of Economics, Business and Management, Vol. 3, No. 4, April 2015

13. Viswanath Venkatesh and Ritu Agarwal (2006) Turning Visitors into Customers: A Usability-Centric Perspective on Purchase Behavior in Electronic Channels, MMAGEMENT SCIENCE Vol. 52, No. 3, March 2006, pp. 367-382 ISSN 0025-19091 EISSN 152655011061520310367

14. https://www.dqinstitute.org/dq-framework/\#digital_intelligence

15. https://dot.gov.in/sites/default/files/statistical\%20Bulletin-2018.pdf

Dated : 19/07/2020 Mumbai, India 